\title{
DESALINASI BERBASIS TENAGA SURYA DI KECAMATAN BAYAN LOMBOK UTARA
}

\author{
Nurul Ismillayli, Dhony Hermanto, Siti Raudhatul Kamali, Fahrurazi \\ Program Studi Kimia Fakultas Matematika dan Ilmu Pengetahuan Alam Universitas Mataram \\ Email: nurulismillayli12@gmail.com
}

\begin{abstract}
Abstrak: Minimnya ketersediaan air bersih dan keterbatasan sarana untuk mendapatkannya membuat masyarakat Kecamatan Bayan, Kabupaten Lombok Utara (KLU) rentan terhadap krisis air. Secara geografis sebagian besar wilayahnya merupakan pesisir pantai yang kaya akan cahaya matahari, mengingat dalam setahun bulan basah hanya terjadi 3-4 bulan. Air laut dapat menjadi bahan baku air bersih melalui teknologi desalinasi dengan menggunakan sinar matahari sebagai sumber panas. Melalui kegiatan Ipteks bagi masyarakat, alih teknologi pembuatan alat desalinasi berbasis tenaga surya di Kec. Bayan, KLU dilakukan. Kegiatan meliputi sosialisasi pada beberapa kelompok tani Kec. Bayan tentang prinsip kerja alat yang telah diuji coba di laboratorium kimia Universitas Mataram. Praktik kerja pembuatan alat juga dilakukan agar kelompok tani dapat membuat alat sekaligus dapat menyalurkan pengetahuan dan keterampilan kepada anggota masyarakat lainnya. Produk kegiatan diharapkan menjadi salah satu alternatif solusi untuk mengatasi krisis air walaupun masih diperlukan peningkatan produktivitasnya.
\end{abstract}

Kata kunci: desalinasi, air laut, air bersih, tenaga surya.

\begin{abstract}
Abstrac: The lack of clean water and limited access to get it made public of Bayan District, North Lombok (KLU) were vulnerable to the water crisis. Geographically, most of KLU is coastal region that rich in sunshine, considering the wet months of the year only occur 3-4 months. Sea water can be the raw material of fresh water through desalination technology using sunlight as source of heat. Through $\mathrm{I}_{\mathrm{b}} \mathrm{M}$ activity, transfer technology by producing and setting desalinator based on solar power in the Bayan district, KLU has been done. The activity included socialization on some farmer groups of Bayan district about basic principle of the desalinator that has been tested in the Chemistry Laboratory at Mataram University. Practicing on production of desalinator also has conducted, hence they can produce and share their knowledge and skills to other community. Product activity is expected to be an alternative solution to overcome the water crisis despite still needed some refinement for increasing its productivity.
\end{abstract}

Keyword: desalination, seawater, fresh water, solar energy.

\section{PENDAHULUAN}

Pengaturan dan penyediaan air bersih sebagai kebutuhan vital manusia merupakan tantangan besar saat ini mengingat permasalahan krisis air bersih terjadi di beberapa daerah di Nusa Tenggara Barat. Dilaporkan bahwa krisis air bersih merupakan salah satu masalah utama yang rutin terjadi setiap tahun terutama di Kabupaten Lombok Utara [1]. Kecamatan Bayan yang memiliki wilayah terluas mencapai $40,65 \%$ dari total luas wilayah mengalami krisis air terparah. Minimnya ketersediaan air bersih dan keterbatasan sarana untuk mendapatkan-nya membuat masyarakat tidak dapat memenuhi kebutuhan air bersih.

Masyarakat memanfaatkan air sumber mata air terdekat yang dialirkan dengan menggunakan pipa atau selang kecil karena jaringan pipa air bersih belum merata dibangun pemerintah setempat. Sedangkan masyarakat yang tinggal jauh dari sumber mata air harus mengebor hingga kedalaman 100 meter lebih atau berjalan hingga $3 \mathrm{~km}$ lebih untuk mendapatkan air bersih [2]. Bila dibandingkan dengan jumlah penduduk, ketersediaan air bersih tersebut tidak dapat mencukupi kebutuhan masyarakat.
Ketersediaan air di Lombok Utara juga dipengaruhi oleh kondisi iklim setempat. Berdasarkan klasifikasi iklim yang dilakukan oleh SchimidtFerguson dengan pemutakhiran data menggunakan Sistem Informasi Geografi terindikasi bahwa dalam setahun jumlah bulan kering lebih banyak dibanding bulan basah [3].

Terlepas dari keterbatasan sarana untuk mengakses air bersih, sebenarnya keberadaan air bersih di bumi ini tidaklah banyak. Air laut menjadi potensi yang sangat besar jika dapat dimanfaatkan untuk bahan baku air bersih. Secara geografis sebagian besar Lombok Utara merupakan pesisir pantai. Selain itu Lombok Utara kaya akan cahaya matahari, mengingat dalam setahun bulan basah hanya terjadi 3-4 bulan. Air laut mengandung kadar garam 3-4,5\% [4] dan TDS (Total Dissolve Solid) tinggi sehingga tidak dapat dimanfaatkan langsung [5]. Akan tetapi, dengan adanya inovasi teknologi, proses produksi air bersih dan layak minum yang berasal dari air laut dapat dilakukan dengan memanfaatkan teknologi desalinasi air laut.

Masyarakat pedesaan di lahan kering Bayan umumnya merupakan masyarakat miskin baik secara ekonomi maupun tingkat pendidikan. Angka 
kemiskinan Lombok Utara pada Tahun 2012 sebesar $35,97 \%$ dan angka partisipasi kasar SMA/SMK/MA/Sederajat sebesar 75,8\% [6]. Dengan permasalahan seperti ini maka strategi pengolahan air laut menjadi air bersih menggunakan peralatan yang murah dan mudah dioperasionalkan.

Pemanfaatan radiasi matahari sebagai sumber panas dapat mengurangi biaya yang dikeluarkan jika dibandingkan menggunakan alat desalinasi termal yang menggunakan listrik atau bahan bakar sebagai sumber panas [7]. Desain alat desalinasi pada kegiatan ini menggunakan plastik/kaca transparan dengan struktur tenda sehingga radiasi panas yang di terima dapat maksimal dan mudah menampung uap air yang terbentuk pada permukaannya. Sebuah baki berwarna hitam digunakan sebagai wadah air laut sekaligus mempercepat penguapan. Uap air yang terkondensasi pada permukaan plastik/kaca akan mengalir turun, terkumpul di dasar sistem. Secara teoritis alat ini dapat menghasilkan 2-4 liter air bersih perhari [8].

Solusi yang akan diterapkan dalam kegiatan ini adalah sosialisasi dan penyuluhan yang diikuti oleh praktek tentang aplikasi alat desalinasi berbasis tenaga surya yang relatif murah dan mudah pada beberapa kelompok tani di Kec. Bayan. Diharapkan kelompok tani tersebut dapat meneruskan pengetahuan pemanfaatan peralatan yang mudah dan relatif murah dalam penerapan alat desalinasi berbasis tenaga surya pada masyarakat sekitar sehingga kebutuhan air bersih setiap KK dapat terpenuhi.

\section{METODE KEGIATAN}

Program pengabdian bagi masyarakat ini bekerjasama dengan dua mitra, yaitu kelompok tani "SPB 212" dan UPTD Dinas Pertanian Perkebunan Kelautan Kehutanan dan Perikanan (DPPKKP) Kecamatan Bayan. Peran mitra kelompok tani sebagai pelaksana kegiatan sedangkan UPTD Dinas Pertanian Perkebunan Kelautan Kehutanan dan Perikanan (DPPKKP) Kecamatan Bayan berperan sebagai penghubung antara penyuluh dengan beberapa kelompok tani di Kec. Bayan dan membantu pemanfaatan dan sosialisasi hasil kerja praktek ini.

Penerapan ipteks dalam kegiatan ini dilakukan melalui beberapa tahap yaitu: 1) sosialisasi dan pertemuan dengan anggota dalam rangka pemantapan kelompok dan pembahasan rencana kegiatan. Kegiatan dilakukan dengan pendekatan melalui upaya pemberian pemahaman dan pengetahuan tentang aplikasi alat desalinasi berbasis tenaga surya yang relatif murah dan mudah serta prinsip kerja alat desalinasi yang telah dioptimasi dan diuji sifat fisik, kimia dan mikrobiologi air kondensatnya, 2) pelatihan praktek kerja oleh kelompok tani di lahan kelompok tani "SPB 212".

\section{HASIL DAN PEMBAHASAN}

Kegiatan sosialisasi dilakukan dengan mengundang beberapa perwakilan kelompok-kelompok tani di Kecamatan Bayan dan beberapa tokoh masyarakat setempat seperti kepala desa dan guru. peserta diberian pemahaman dan pengetahuan tentang pentingnya air bersih dan bagaimana mendapatkan air bersih dengan mengolah air laut yang semula tidak layak dikonsumsi menjadi air tawar yang layak konsumsi melalui teknologi sederhana seperti desalinasi berbasis tenaga surya.

Pemaparan materi tentang prinsip dasar alat desalinasi dan bagaimana cara membuat alat dengan memanfaatkan bahan-bahan yang tersedia dan terjangkau harganya menjadi materi inti yang disampaikan pada sosialisasi ini.

Prinsip dasar alat desalinasi adalah ketika alat desalinasi terpapar sinar matahari, radiasi matahari masuk melalui kaca penutup transparan menuju ke dalam wadah air laut. Sifat konduktivitas panas yang baik dari wadah aluminium menyebabkan temperatur pada alat desalinasi, baik itu berupa suhu kaca, ruangan, suhu air meningkat seiring dengan meningkatnya intensitas matahari. Suhu di dalam ruangan lebih besar daripada suhu lingkungan, hal ini disebabkan oleh adanya transmisi panas dan terperangkap di dalam alat desalinasi. Air laut kemudian menguap dan menempel pada kaca penutup bagian dalam. Proses kondensasi dipengaruhi oleh suhu kaca penutup ruang evaporasi. Uap yang terbentuk akan terkondensasi apabila mengenai kaca penutup yang suhunya lebih rendah. Hasil kondensasi menempel pada kaca penutup bagian dalam dan mengalir ke bawah mengikuti kemiringan kaca penutup. Hasil kondensasi ditampung dan menghasilkan air tawar. alat adalah

Hal-hal perlu disampaikan terkait dengan seting

a. Alat desalinasi secara garis besar terdiri dari 3 komponen utama yaitu wadah air laut, penutup sebagai tempat terjadinya kondensasi dan penampung air tawar. Ketiga komponen tersebut terbuat dari bahan yang mudah diperoleh, tahan lama dan harganya relatif terjangkau oleh masyarakat luas.

b. Wadah air laut yang digunakan harus tahan korosi dan memiliki sifat konduktivitas panas yang baik.

c. Geometri dan kemiringan kaca penutup berpengaruh terhadap produktivitas alat. Bentuk kedua prototype yang telah diuji ditampilkan pada Gambar 1. Prototipe A mampu menghasilkan air kondensat 428-470 mL tergantung pada intensitas matahari yang diterima. Sedangkan prototipe B mampu menghasilkan air kondensat 350-428 mL. Prototipe A memiliki sudut kemiringan lebih landai memungkinkan intensitas sinar matahari yang diterima wadah aluminium lebih banyak dibanding prototipe $\mathrm{B}$ sehingga prototipe A lebih cepat mengalami peningkatan suhu dan air laut pada prototipe A lebih cepat menguap. Proses penguapan akan semakin baik apabila suhu air laut dalam wadah aluminium semakin tinggi. Sedangkan proses pengembunan akan semakin cepat terjadi bila suhu kaca penutup semakin rendah. 


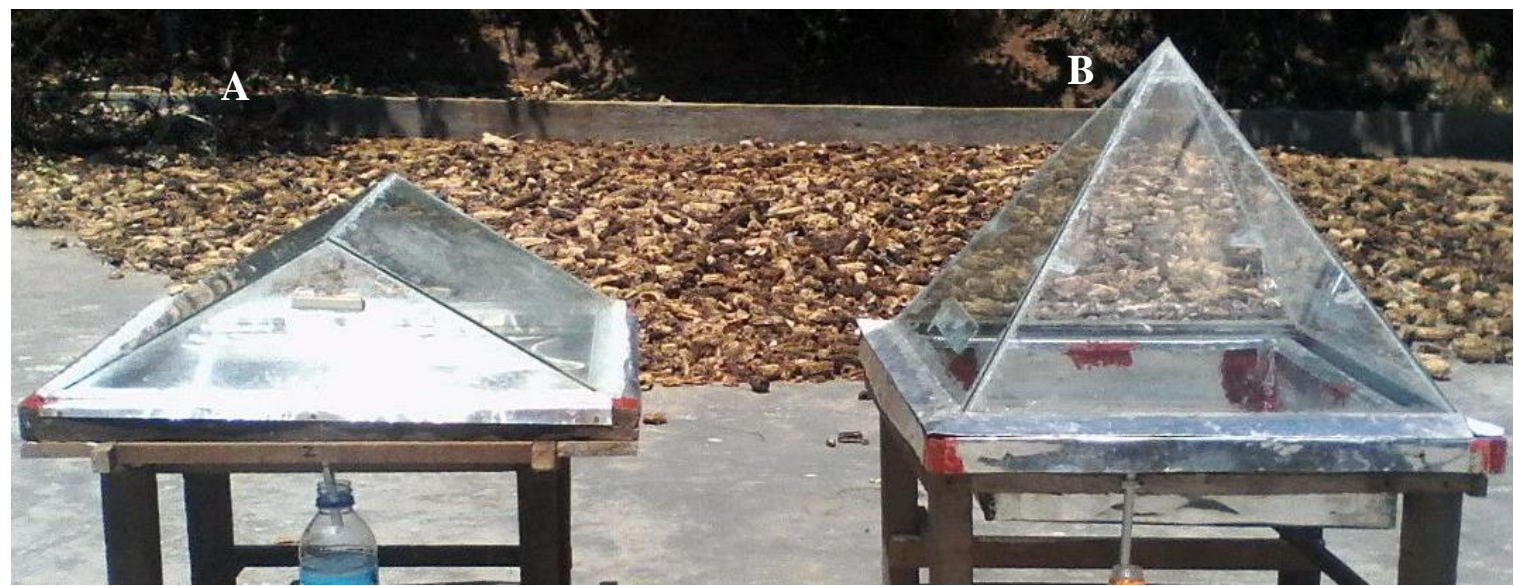

Gambar 1. (A) Prototipe bentuk prisma segitiga dan (B) Prototipe bentuk limas

d. Alat desalinasi harus rapat artinya tidak boleh ada celah antara wadah air laut dengan kaca penutup sehingga kebocoran uap air dapat diminimalisir.

e. Ketinggian air yang ada di dalam alat desalinasi \pm $2 \mathrm{~cm}$ dari dasar wadah. Semakin banyak air di dalam wadah maka proses penguapan air semakin lama. Tetapi, jika air dalam alat desalinasi terlalu sedikit maka alat dapat rusak karena terlalu panas mengakibatkan kaca penutup menjadi retak.

f. Air hasil kondensasi alat desalinasi berbasis tenaga surya merupakan air dengan kualitas low minerals dan aman dikonsumsi.

Metode sosialisasi yang digunakan adalah ceramah dan dilanjutkan dengan diskusi/tanya jawab untuk mengetahui sejauh mana pemahaman peserta dalam menerima materi. Kegiatan sosialisasi dilanjutkan dengan praktik pembuatan alat. Peserta sangat antusias mengikuti kegiatan ini, diindiasikan dengan banyaknya pertanyaan-pertanyaan yang diajukan terutama mengenai teknis pembuatan alat, produktivitas alat desalinasi dan keamanan konsumsi air kondensat yang dihasilkan alat desalinasi. Peserta merespon positif terhadap alih teknologi ini karena alat desalinasi dibuat dengan menggunakan bahan yang tersedia dengan harga terjangkau dan teknik produksinya relatif sederhana. Peserta berharap produk kegiatan berupa informasi dan teknologi tepat guna dapat menjadi salah satu alternatif solusi mengatasi krisis air di daerah setempat.

\section{KESIMPULAN}

Telah dilakukan sosialisasi dan praktik pembuatan alat desalinasi air laut menjadi air tawar berbasis tenaga surya dengan menggunakan bahanbahan yang tersedia dan murah dengan teknik pembuatan yang sederhana. Respon masyarakat sangat baik dan aktif selama pelaksanaan kegiatan dan berharap produk kegiatan ini merupakan alternatif solusi untuk mengatasi krisis air walaupun masih diperlukan beberapa penyempurnaan alat desalinasi untuk meningkatkan produktivitasnya.

\section{UCAPAN TERIMA KASIH}

Ucapan terimakasih disampaikan kepada pihak DP2M KEMENRISTEK-DIKTI yang telah memberikan dana kegiatan pengabdian kepada masyarakat pada tahun 2016 melalui skim Ipteks bagi Masyarakat (IbM). Ucapan yang sama disampaikan kepada kelompok-kelompok tani Kec. Bayan terutama kelompok tani "SPB 212" dan UPTD Dinas Pertanian Perkebunan Kelautan Kehutanan dan Perikanan (DPPKKP) Kecamatan Bayan.

\section{DAFTAR PUSTAKA}

[1] Suara Komunitas, 2011, Dusun Tebayak, Lombok Utara Kesulitan Air Bersih, http://suarakomunitas.net/ dusun-terbayak-lombok-utara-kesulitan-air-bersih/, diakses tanggal 30 Desember 2015.

[2] NTB terkini, 2012, 17 Dusun Di Lombok Utara Kekurangan Air Bersih,http://ntbterkini.com/17dusun-di-lombok-utara-kekurangan-air-bersih/, diakses tanggal 30 Desember 2015.

[3] As syakur A.R., 2005, Aplikasi Sistem Informasi Geografi (SIG) untuk Pemutakhiran Peta Agroklimat Pulau Lombok Berdasarkan Klasifikasi Oldeman dan Schimdt-Ferguson, Skripsi, Universitas Udayana, Denpasar.

[4] Sasakura. 1995. Desalination Tech-nology and Its Aplication, P.T. Sasakura Indonesia, Jakarta

[5] Said, N.I., 2010, Pengolahan Payau menjadi Air Minum dengan Teknologi Reverse Osmosis, http://www.kelair.bppt.go.id/Publikasi/BukuAir Minum/BAB10RO.pdf

[6] Pemerintah Kabupaten Lombok Utara, 2014, Laporan Akuntabilitas Kinerja Instansi Pemerintah, http://lombokutarakab.go.id/2014/lakipklu2013. pdf 
[7] Jitsuno, T. and Hamabe K. 2012. Vacuum Distillation System Aiming to Use Solar-Heat for Desalination. Journal of Arid Land Studies. 22(1): $153-155$.

[8] Bethel Jr. S.G., Dell'Accio, D.V., Haffenreffer, M.F., Modest, Z.T., Wegma,M.B., 2012, LowCost Solar Desalination Device, http://www.mie.neu.edu/ME_2012_04_LowCost_.pdf 